\title{
Timber beds, protests \& publics: conflicting meanings of the public interest on Devonshire Street, Sheffield
}

Article

Accepted Version

Maidment, C. ORCID: https://orcid.org/0000-0002-9158-6910 (2021) Timber beds, protests \& publics: conflicting meanings of the public interest on Devonshire Street, Sheffield. Town Planning Review, 92 (4). pp. 587-614. ISSN 1478-341X doi: https://doi.org/10.3828/tpr.2021.25 Available at https://centaur.reading.ac.uk/98510/

It is advisable to refer to the publisher's version if you intend to cite from the work. See Guidance on citing.

To link to this article DOI: http://dx.doi.org/10.3828/tpr.2021.25

Publisher: Liverpool University Press

All outputs in CentAUR are protected by Intellectual Property Rights law, including copyright law. Copyright and IPR is retained by the creators or other copyright holders. Terms and conditions for use of this material are defined in the End User Agreement.

www.reading.ac.uk/centaur 
Central Archive at the University of Reading

Reading's research outputs online 


\title{
Timber Beds, Protests \& Publics: \\ Conflicting Meanings of the Public Interest on \\ Devonshire Street, Sheffield
}

\author{
Christopher Maidment \\ The University of Reading
}

\begin{abstract}
This paper discusses a case small in scale, but one which raises questions around how different conceptions of what is in the public interest are reconciled in the English regulatory planning system. The case in question is the proposed redevelopment of three 1850s shops in Sheffield's Devonshire Quarter, traditionally home to independent retailers.
\end{abstract}

The paper illustrates how a small scale planning application can generate national attention, through a range of misunderstandings, conflicting interests and a narrow definition of what constitutes knowledge in English planning. Particular attention is paid to how a different approach to decision-making might have facilitated a compromise solution, through thinking about what is in the public interest at different scales.

The core argument is around the need to address how public participation in planning processes can be based on more equitable use of knowledge. This leads to conclusions around how the system can better reconcile multiple interests.

\section{Introduction}

This paper explores how tensions between multiple discourses are resolved, or not resolved through a case study of a planning decision, whose complexity belies its small-scale. It draws on the author's experience of spending four years working on a doctoral thesis, whilst simultaneously working for a business making timber beds, the relevance of which lies in the sale of beds as an activity requiring suitable spaces in which to manufacture, display and sell them. Whilst grounded in the individual building scale, the case's complexity results from processes and values operating at multiple scales and its cumulative role within these.

In particular, the paper focuses on the interaction between regulation and discretion that, to date, characterises decision-making in the English planning system, with a view to making decisions that are in the public interest. This distinctive legislative principle assumes development plan policies take precedence but leaves space for persuasive arguments that they should be departed from (HM Government, 2004). This is described by Reade (1987, p.II) as sitting on 'a spectrum from pure rule of law at one end to pure administrative discretion at the other', striking a balance between regulations governing entirely what is permitted, and being entirely flexible and open to negotiation over individual proposals. 
Conversely, this case is used to illustrate three key arguments stemming from a perceived lack of discretion; the mismatch between the values and interests expressed in multiple ways through public participation, and the much narrower framing of the decision-making process, structured by regulation that codifies only some values; the lack of space for mutual-learning and modification of interests within this process; and the consequent inability of the system to reconcile the values and interests of multiple publics, defined at multiple scales.

The result was the approval of an application that provoked widespread public objection, including more than 700 written comments, petitions signed by tens of thousands and a range of journalistic accounts. Consequently this raises questions around the version of the public interest embodied in the decision.

To set the scene for addressing these issues, the paper first introduces the case study proposal in more detail, before setting out the tools that will be used to explore it in depth.

\section{162-I70 Devonshire Street, Sheffield}

162-170 Devonshire Street is located on Sheffield City Centre's western edge, within a city of around half a million people. Following the steel industry's decline, Sheffield's economy has diversified but still includes aspects of precision metallurgy, producing cutlery and surgical instruments amongst other items. There is ambition for the wider Sheffield city region to become home to higher value activities, that combine traditional manufacturing with the "knowledge economy', manifested in activities such as advanced manufacturing for the automotive and aerospace industries and, most relevant here, the digital and creative industries (SCR, 20I5).

Within Sheffield, Devonshire Street has a reputation as home to independent retailers, formally recognised in documents such as the Devonshire Quarter Action Plan (SCC, 2000) and the City's current statutory spatial plan; the Sheffield Core Strategy (SCC, 2009). Generally, this character remains intact, if diluted by the arrival of chains such as Subway, Pizza Express and Taco Bell. However, the surrounding area has changed considerably, with the West One complex (completed 2005) of mid-rise apartments above restaurants and shops bringing a contemporary/generic 'big city' feel.

The building in question is a row of three small shops, each three storeys high, as illustrated in Figure 2. Behind each shop is a yard, of a similar footprint to the building itself, now mainly used for parking cars. In 2014, reflecting Devonshire Street's reputation, each of the three shops was occupied by an independent business. Although originally built prior to the 1850s (Wessex Archaeology, 2015) and surviving extensive bombing of the area during World War Two, these buildings are not subject to the legal protection that listing for heritage value brings, with significant consequences. Devonshire Street itself maintains several buildings from this era, some of which are listed for their historical integrity. 


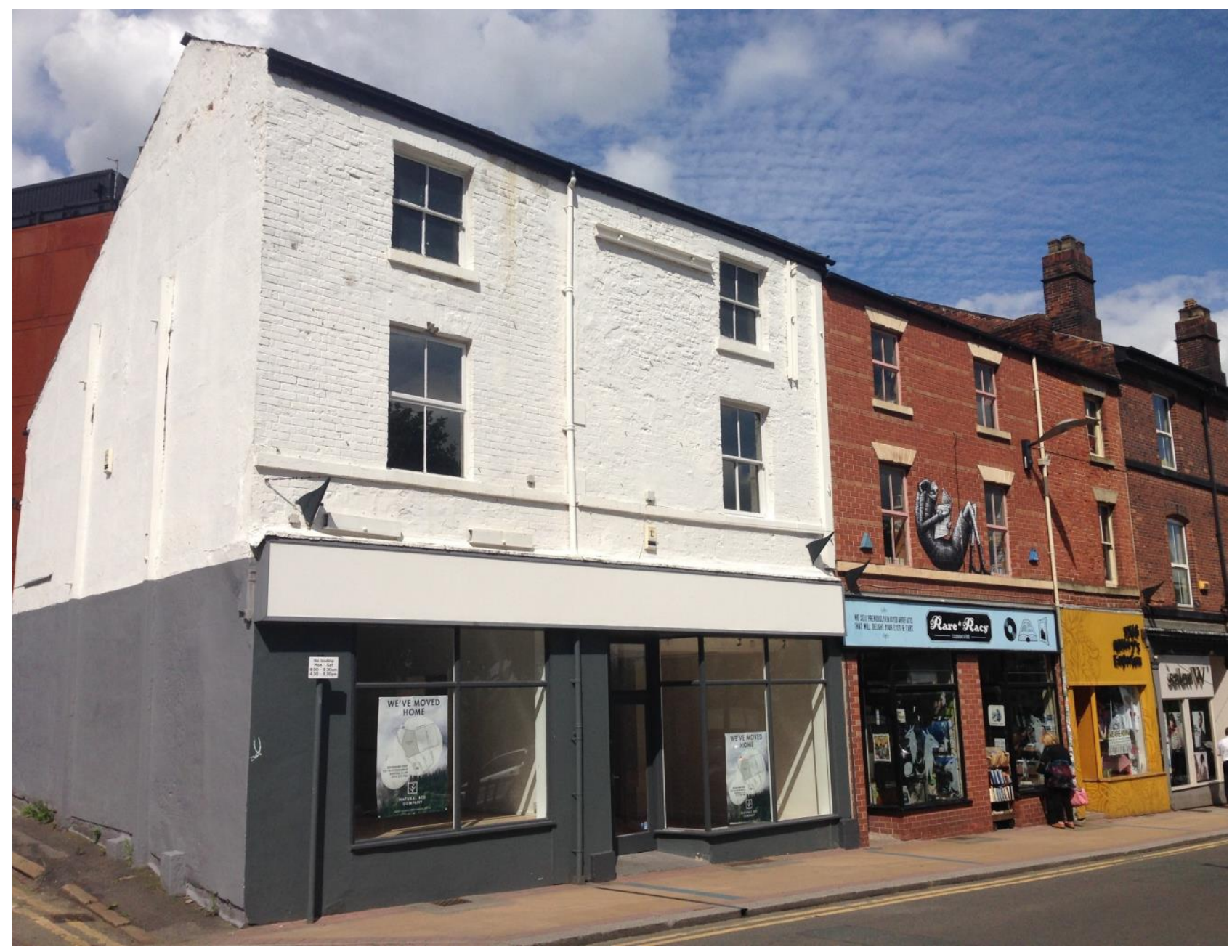

Figure 2: 162-170 Devonshire Street (Source Author, taken June 20 I6)

In September 2014, a planning application submitted to Sheffield City Council (SCC) proposed the site's demolition and redevelopment, to accommodate a ground floor restaurant of 400 square metres with fourteen studio apartments above (Hope, 2015). From the street the redeveloped site would appear as a like-for-like replacement of the existing building, intended to have the same proportions and architectural details. The yard would be developed as apartments of contemporary design (Coda Planning, 20I5). In March 2015 the proposal was approved by the Council's planning committee, despite the aforementioned public opposition.

Following from the principle of discretion, a key feature of the English planning system is the process of weighing up different values, translated into regulation in more or less detail. The terminology used is 'material considerations', where the tests of this are whether they relate to land use and whether they are in the public interest. It is otherwise an open-ended definition, and for the decision-maker to determine what constitutes a material consideration and what weight it should be given (MHCLG, 2020).

Typically, when a planning application is submitted, a case officer is assigned to weigh up all of the considerations and reach either a delegated decision, or recommendation to the elected politicians who form the planning committee, on whether the proposal should be approved or refused. Whilst not a statutory requirement, the weighing up is often recorded in the form of an 'officer report', particularly where decisions are made by committee. Characterising this as weighing up 
'values' emphasises the inherent subjectivity that might lead to different professional judgements resulting from the same considerations.

Within the proposal's description a range of values are implicit, from heritage and independent business, to economic growth and urban sustainability. This reflects the complexity of values and interests bound up in even small-scale planning decisions, but also raises the question of what constitutes 'valid' knowledge in planning; later discussion will illustrate how the officer's report is narrowly framed around valid, codified planning concerns, whilst explicitly rejecting others. This leaves open to question whether the decision-making process allowed, or should have allowed, the full range of values to be accounted for; is the proposal's approval fully in the public interest?

\section{Case Study Methodology}

To facilitate this, the case study is explored in depth through a secondary qualitative analysis of a range of written materials used in the decision-making process. These include the planning application documents themselves, the officer's report, and various media articles published about the case, with a focus on how language is used to frame the proposal and decision-making process.

An analysis of published public comments on the application is presented (See Table I), identifying key themes and how they were framed. To achieve this, the views of commenters were broken down into individual points and reasons, each of which was coded with a dominant theme.

Finally, the author's own reflections on being in the midst of the case, as an employee of one of the businesses affected, are used to add an additional, if more subjective, dimension, through anecdotal reflections on how the documented proposal was understood (and misunderstood) by the business' customers.

To systematically work through these multiple interests a conceptual framework is adopted, bringing together multiple conceptualisations of the public interest through the lens of scale. The paper now explores this framework in more detail.

\section{In the Public Interest? At What Scale?}

The framework adopted here draws on different conceptualisations of the 'public interest'; the idea that planning is about creating places for wider society, not only those seeking to profit financially from the built environment. Despite the concept's historical association with imposition rather than facilitation, Campbell and Marshall note that it 'remains the pivot around which debates about the nature of planning and its purposes turn' (2002, p.18I). Similarly, the Royal Town Planning Institute continues to define the role of planners to 'pursue the science and art of town planning for the benefit of the public' $(2016$, p.2). This provokes the question of who and what constitutes the public in relation to the Devonshire Street proposal?

To address this question, a theme from the author's previous work is further developed, linking the definition of the public interest to scale, in terms of time and geography (Maidment. 2016), with implications for how decisions are made. This provides a point of comparison for how the decision was made within the regulatory system.

Fundamental to this understanding of the public interest is Dewey's (1954) conception of the public as those affected by the wider impacts of a private decision, but who are unable to directly 
influence that decision. Within the English planning system everyone outside of the decision would typically be considered part of the public. However, Dewey's conception distinguishes between those who are impacted but closely related enough to organise and address these impacts, and a wider group; also affected but too dispersed to effectively organise, highlighting the usefulness of thinking about the public in terms of scale.

In turn, this reflects how the officer report and, ultimately, the decision-maker(s), must strike a balance between those able to express their interests, and those who have an interest but are less able to express it. This aligns, respectively, with conceiving of the public interest as arrived at through a dialogical process, and assuming that those who cannot express their interests share a 'common good'.

\section{Abstract, Dispersed Publics}

For Dewey only the latter group are truly a 'public' and require an external body to identify and address these 'spillover' effects on their behalf'. Such publics are more abstract and it is more difficult to identify specific impacts on their interests. However, in addition to the 'silent majority', they might include future generations; recognising that today's decisions will inextricably shape tomorrow's world (e.g. Makoff \& Read, 2018), geographically distant others; recognising that environmental problems do not confine themselves to the container boundaries of nation-states (e.g. Fraser, 2008; O'Neill, 2000; Young, 2000) and other species; recognising these cannot have voice in decisions affecting them (e.g. Nussbaum, 2008).

Consequently, some planning decisions impact publics that can never practically participate in decision-making processes and rely on their interests being represented in other ways. This 'common good' approach to the public interest (Campbell \& Marshall, 2002) requires decisionmakers to assume what constitutes their shared interests, but might encompass non-negotiable goals, such as avoiding environmental degradation or furthering fundamental rights to shelter. Although not specifically about planning, the Well-being of Future Generations (Wales) Act (National Assembly for Wales, 2015) illustrates this approach. The Act mandates Welsh public bodies to consider future generations in decision-making, by setting objectives that respond to seven well-being goals, but leaving open how these translate into individual decisions.

Superficially, the impact of small scale planning applications on these publics appears limited, until their cumulative impact is considered; each individual planning decision makes a small step either towards or away from common good-type goals, as illustrated by the later analysis of the Devonshire Street proposal. Dewey's formulation underpins the role of regulation in addressing these goals; policy and legislation can be characterised as predicting the spillover consequences of decisions and regulating for these, whilst leaving space for discretion. However, this leaves open the question of how more-localised and/or non-regulated interests can be accounted for.

\section{Diverse, Localised Publics}

In the context of better understanding society's diversity, and the need to advocate for a plurality of interests in planning processes (Davidoff, 1965), communicative theory represents a positive

\footnotetext{
${ }^{1}$ Whilst the external body might sound like the 'state', Dewey intended for it to be a fluid concept, adaptive to different needs, rather than concerned with maintaining its own power and sovereignty.
} 
way of arriving at collective outcomes from positions of difference, through mutual learning (Healey, 2006). Emphasising dialogue and consensus over imposition, such approaches arguably allow more-localised publics, with greater potential to self-organise, to engage in decision-making processes; in turn, the impacts of new development on those living and working in the vicinity, which often cannot be captured as 'technical' knowledge, should be enrolled in any consensus decision reached.

Conversely, communicative approaches, as about power-neutral, consensus decision-making, are incompatible with the current English system of making decisions on individual proposals ${ }^{2}$. As later discussions will show, statutory opportunities for public consultation on individual planning applications are not designed to accommodate a process of learning about and modifying interests, but can only account for interests as they are defined at a particular point in time. More fundamentally, the lack of space to judge the appropriateness of a consensus decision leaves open the issue of ensuring that the interests of more dispersed, abstract publics are also accounted for.

Other critics of communicative theory focus on the danger that those involved are required to moderate or hide their true interests in favour of seeking a consensus (McClymont, 20I I) and may be too accustomed to the adversarial processes that more typically characterise planning (Hillier, 2004). Instead, they highlight the potential of agonism; an adversarial approach where participants see each other as having conflicting interests, incorporating the full and frank exchange of views that characterise antagonism, but without the same annihilistic ends in mind (Mouffe, 2005). McClymont (20II) highlights the planning appeals process as an example of this in the English system, where a Planning Inspector's judgement replaces the need for consensus, allowing each participant to put forward their interests vociferously. In contrast to communicative approaches and Mouffe's (2005) formulation of agonism, this approach makes space for judgement in the outcome.

In the Devonshire Street case, the officer report can be characterised similarly; its recommendation (informing elected members' judgement as decision-makers) is based on different groups putting their interests forward persuasively, (partially) expressed through participation, balanced against the interests of more-abstract publics, including those translated into policy and regulation. However, when compared to a planning appeal, comparatively unequitable access to development management processes also highlights the role of power and information accessibility in allowing equitable participation. In turn, the planning officer's ability to choose which rationales are admitted into the process highlights their ability to exert power (Forester, 1989). It is therefore useful to highlight how interests might be rationalised using multiple knowledges.

\section{Multiple Rationalities, Multiple Public Interests \& the Planner}

As a starting point, the change in terminology from 'public good' to 'public interest' is notable (Flathman, 1966); 'good' embodies more-abstract, implicit ideas of the right thing to do, a matter of values; 'interest' implies an explicit stake in decision outcomes, requiring the rationale behind each value or interest to be identified. Simultaneously, there is a need to recognise that rationales might be underpinned by wider a range of knowledges than the 'technical' knowledge traditionally

\footnotetext{
${ }^{2}$ Healey (2003) specifically recognises that the ideals of collaborative planning are not fully achievable within institutionalised planning systems.
} 
valued in planning decisions (Healey, 2006; Sandercock, 1998). Sandercock (1998) highlights six lay knowledge types associated with day-to-day practices:

- Dialogical knowledge; generated through interaction between different groups.

- Learning-by-doing; knowledge is generated by engaging in activities.

- Symbolic knowledge; taking non-verbal forms such as art and poetry.

- Contemplative knowledge; resulting from reflecting on situations.

- Local knowledge; practically-acquired understandings of how places work.

- Tacit/experiential knowledge; gained through experience without always being clear on its origins, including aesthetic appreciation and emotional attachment.

Sandercock's typology is useful for examining how public input into planning processes might tend towards different knowledge types, and forms a basis for analysing written comments on the Devonshire Street case (see Table I). However, this should not imply absolute boundaries between lay knowledge types. For example, where knowledge is drawn into the process in reaction to a proposal, this might all be considered contemplative knowledge. Similarly, within the development management process, where participation is currently organised around written and verbal comments, symbolic and learning-by-doing knowledges are arguably less compatible than local and tacit knowledges.

In identifying how different interests are rationalised, recognising the potential for rationality to be limited by lack of knowledge is also important; a key theme is the extent to which this limited the power and influence of some parties to shape the Devonshire Street proposal.

In summary, if the scale of the public is adopted as a lens for addressing which conceptualisation of the public interest should drive practical action, the planner's role may be restated as about pursuing the public interest as the synthesis of multiple publics with multiple interests, expressed through multiple processes and knowledges (Campbell, 20I2). It is a mode of planning that relies on making situated judgements about how different interests and values should influence a decision (Campbell, 2006). As a normative model, this provides a useful tool for assessing the extent to which this could be practiced in relation to the Devonshire Street proposal, within the regulated structures of the English planning system.

\section{Macro-scale values associated with the Proposal}

The work now turns to identifying more-abstract values associated with the proposal, illustrating its impacts on widely dispersed publics, followed by those identified through participation in the planning process.

\section{Urban Sustainability}

The application proposes fourteen additional apartments on an under-utilised yard, within walking distance of a light-rail network, green space in the form of Devonshire Green, Sheffield's two universities and the shops, services, jobs and activities associated with a vibrant city centre. It arguably represents the high density, city centre development crucial to maintaining compact urban form in the face of global population growth, and to reducing private vehicle reliance in the face of climate change. 
Without promoting radical lifestyle changes, the proposed development can, in principle, be said to support environmental and social sustainability as they are conventionally understood. Both are goals in the 'common good' tradition; environmental sustainability in particular creates a public that is global in scale, including future generations and other species.

Conversely, the extent to which the proposal's detailed design minimises its environmental impact is limited; a 'Sustainability Statement' submitted with the application refers to exploring renewable energy and local materials usage, but makes no specific commitments (Coda Planning, 20I4). Additionally, no reference is made to recycling or reusing materials from the existing building, noteworthy given the significant concerns around heritage value that will be discussed. This is not unusual in a context where national policy allows local renewable energy policies to be overridden when they are not financially viable, including a significant developer profit margin (MHCLG, 2019), limiting the extent to which environmental sustainability can be addressed through the cumulative impact of local decisions on new proposals.

\section{Addressing Housing Need}

The national context for the proposal is a political consensus around a significant housing shortage in England. Addressing this is only in the direct interest of parts of society, particularly younger generations unable to access home ownership, afflicted by increasing rents and insecure tenancies. However, if simplified to a fundamental right to shelter, it is another value that can characterised as a common good-type goal.

Thinking about housing shortage in abstract terms, new apartments contribute to addressing this. In turn, the Officer Report details how SCC negotiated to alter the proposal from fourteen studio apartments to a mix of twelve studio, one-bedroom and two-bedroom apartments, to better address housing need in Sheffield (Hope, 20I5). Within the wider value of rights to shelter, this can be framed as accommodating the interests of a more-localised public.

\section{Conflicting Values, Multiple Public Interests}

The case's most striking aspect is the significant public concern that it generated, manifested through multiple outlets. This can be identified as representing the interests of more-localised publics; those able to participate in the decision-making process. Similarly striking is how such concerns were often misinformed and focussed on issues that do not fit comfortably into the regulatory planning system as it is currently codified. This leads to questions about how public debate on specific proposals can be better informed, and public concerns better accounted for. This section explores the values and interests expressed, and the participative mechanisms used to enrol them in the process.

\section{Heritage Value}

Of the two values most dominant within the concerns, heritage is long established as a matter for regulation. National policy is more explicit about how 'designated heritage assets' should be treated, but also characterises the significance of 'non-designated heritage assets' as a material consideration, albeit leaving the corresponding weight to the decision-maker's discretion (MHCLG, 2019). 
Externally, the shops appear much as when first built. Their age would usually see them protected through listing, as 'most buildings that retain a significant proportion of their original fabric are likely to be regarded of special interest' (p. 6, DDCMS, 2018). Going inside explains why these buildings are not but also raises questions around where heritage value sits on the continuum between technical knowledge and emotional attachment, driven by aesthetic knowledge, or by the material substance of the building's construction.

Internal modifications for use by different occupiers have left little of the original fabric intact. A Structural Condition Report (Eastwood \& Partners, 2014) confirms that the third storey is occupied by a steel beam, essentially holding the building together. Meanwhile, part of the outer wall of one shop has been rebuilt, identifiable from bricks much newer and more uniform in shape than the originals (See Figure 3). The Report concludes:

...the present overall structural condition of the three buildings appears to be generally adequate, considering their age, but there are a number of issues with potential to become a significant safety risk in the longer term.

Overall, the applicant's preference to demolish rather than adapt the existing building, can be seen as prioritising their own, measurable, financial profit, over the building's intrinsic historic value, which cannot be fully codified.

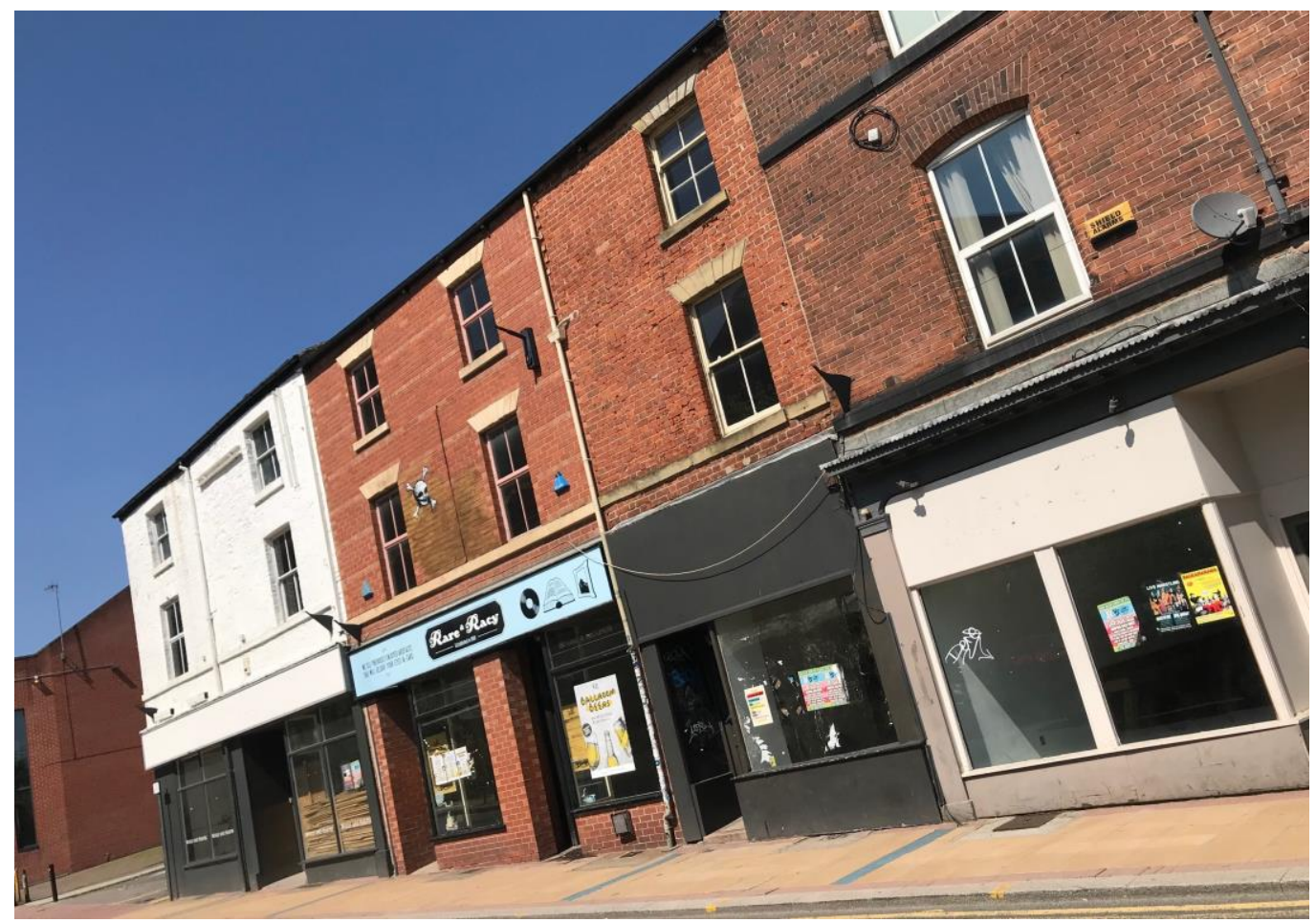

Figure 3: The Existing Front Elevation, including the replacement front wall at I 66 Devonshire Street (Source Author, taken May 2018)

\section{Independent Business}

By contrast, the nature of a shop's tenant has, to date, been considered largely beyond the scope of planning regulation. Conversely, the importance placed on businesses perceived as independent 
was a core theme of public reactions to the proposal, highlighting the disconnect between values considered inside and outside the system.

In 2014 the building was home to three businesses; a second-hand book and music store with more than 45 years of history (Rare \& Racy), a more recently arrived local clothing brand (Syd \& Mallory's) and the aforementioned bed shop with a 40 year history (Natural Bed Company). At time of writing, the building still stands but stands empty. The independent clothing label has found a new home a few doors further down Devonshire Street. The bed store has moved only a street away, into brand new, more spacious accommodation, but no longer in a part of the city centre with regular footfall. Rare \& Racy has ceased trading.

Each of the three fit the basic meaning of 'independent' by being one of a kind, with no branches elsewhere. This can also be characterised as a widely shared value, rationalised by asserting that maintaining retailer diversity prevents gradual monopolisation and homogenisation of consumer choices in an era of agglomeration. However, it is, again, difficult to codify absolute characteristics that define an 'independent business', instead it is a matter of judgement. The implication is that the financial profit associated with independence is more valuable than the profit associated with larger chains. Conversely, the greater tendency for independent businesses to be locally anchored, with more of their income reinvested in the local economy, is a normative value with a degree of measurability (Locality, 2017).

The space requirements of such businesses can be more easily understood. Arguably the dilapidated state of the premises provided relatively small spaces with inexpensive rents, in a location with significant footfall, allowing businesses to establish themselves. To use the bed store as the business with which the author is most familiar, this traded from Devonshire Street for more than twenty-five years, growing to the point that new premises were seen as an opportunity for showroom expansion. The proposed redevelopment and loss of small retail spaces will no longer provide this opportunity for other businesses to evolve ${ }^{3}$.

\section{The Extent of Public Concern}

The introduction highlighted the juxtaposition between the small physical scale of the buildings involved and the extensive public reaction. This section narrates the mechanisms used by a range of groups to communicate this reaction, with the aim of influencing the decision. The analysis considers the extent to which their reaction is based on values or direct interests, and influenced by misinformation or a limited understanding of the planning system, the latter highlighting the lack of opportunity for mutual learning and interest modification.

\section{Thematic Analysis of Public Comments}

The public have a statutory period of two weeks to make written comments on planning applications (HM Government, 20I5). It is then for the case officer to judge how comments should influence decision-making.

\footnotetext{
${ }^{3}$ These debates are reflected in the decision of Network Rail, the public sector owner of the UK's railway infrastructure, to sell off small, low rent spaces located under railway bridge arches (Davies, 2018). A report to central government found that Network Rail failed to consider the interests of tenants and government aims to promote small and medium-sized enterprises (HCCPA, 2019).
} 
Providing a subjective insight into the scale of public concern, more than 700 written comments of varying length were made on the Devonshire Street application, covering a range of themes and providing an extensive dataset for understanding wider views on the proposal. These notably included objectors from distant cities such as London and Newcastle, highlighting that the process does not start with a localised, bounded public in mind. Analysing these comments shows they are dominated by a small number of themes, but also how they are rationalised by drawing upon multiple knowledge types and through claims to represent different publics.

Table I summarises the core themes identified from the comments and presents examples that represent different knowledge types. As earlier noted, the lay knowledge types are taken from Sandercock's (1998) typology, with a focus on those that can be enrolled in a system of recording written comments. Comments are categorised by their tendency toward technical knowledge, local (practical) knowledge and tacit/experiential knowledge. Tacit/experiential knowledge is further divided into comments that express an emotional attachment to place, and comments drawing on aesthetic experience. Again, it must be acknowledged that these are artificial divisions, given the appeals to emotion expressed in all comment types. However, Table I does illustrate the range of ways in which the comments try to persuade the case officer to recommend the proposal's refusal.

Superficially, the majority of comments focus mainly on the building's heritage value and the loss of independent businesses, suggesting widespread consensus around these values. However, as Table I illustrates, there are important variations in how the comments are framed, with consequences for how they fit into the planning system as it currently organised. Whilst comments in the 'technical' column refer to the Council's own policies, making points that fit within the traditional understanding of planning as a regulatory process, these form a minority; most comments are grounded in experiential knowledge of the area, with many making emotive appeals to maintain the shops as part of Sheffield's character; a combination of the building's history and the experiences resulting from the nature of the businesses operating from them.

Building on this, whilst many commenters highlight their personal enjoyment of the businesses and the importance of this to their experience of living in Sheffield, they also place this within a wider context. A consistent theme was to highlight the character and independent nature of the Devonshire Quarter as fundamental to Sheffield's unique appeal; commenters suggested that the proposal would lead to comparisons with undesirable places, with Leeds and Milton Keynes given as examples. For many, the area was cited as an attractor when choosing to move to Sheffield, a clear example of a rationale grounded in local, practical knowledge:

...I can say from experience that this area was one of the selling points of Sheffield when I was choosing between university offers... having an interesting and unique city centre is one reason among many that I have stayed and kept my skills in the city post-graduation.

(Anonymous, 2014) 


\begin{tabular}{|c|c|c|c|c|}
\hline \multirow{2}{*}{$\begin{array}{c}\text { Knowledge } \\
\text { Type }\end{array}$} & \multirow[t]{2}{*}{ Local/Practical Knowledge } & \multicolumn{2}{|c|}{ Experiential } & \multirow[t]{2}{*}{ Technical } \\
\hline & & Emotional & Aesthetic & \\
\hline $\begin{array}{c}\text { Independent } \\
\text { Retail/ } \\
\text { Business }\end{array}$ & $\begin{array}{l}\text { 'They are a haven for individuality and } \\
\text { creativity in a mass produced } \\
\text { world... The lack of support from the } \\
\text { council for small businesses is } \\
\text { terrible... Please try harder to help } \\
\text { these traders to carry on their } \\
\text { business.' (36) }\end{array}$ & $\begin{array}{l}\text { 'It would be a gross misjudgement to } \\
\text { get rid of these independent businesses. } \\
\text { To rip out the area and replace it with } \\
\text { soulless commercial... will decimate the } \\
\text { heart of the Quarter... Squandering } \\
\text { what little local businesses we have left } \\
\text { would hurt the city.' (2) }\end{array}$ & & $\begin{array}{l}\text { 'The Devonshire Quarter Action Plan } \\
\text { was put together by the City Council in } \\
\text { conjunction with local residents... This } \\
\text { states quite clearly that no more than } \\
30 \% \text { of any block can be AI and as the } \\
\text { Green Room already takes up a } \\
\text { considerable proportion of this block, } \\
\text { then no more can be allowed...' (7) }\end{array}$ \\
\hline $\begin{array}{l}\text { Heritage } \\
\text { Valuel } \\
\text { Building } \\
\text { Condition \& } \\
\text { Reuse }\end{array}$ & $\begin{array}{l}\text { 'This street is an iconic piece of } \\
\text { Sheffield Blitz history!... To demolish } \\
\text { this would: I) further degrade the } \\
\text { historic built environment of Sheffield } \\
\text { city centre, 2) remove well-used } \\
\text { existing buildings that have high } \\
\text { amenity value, 3) go against the area } \\
\text { of special character, suggesting that } \\
\text { SCC places no value on such } \\
\text { designations...'(5) }\end{array}$ & $\begin{array}{l}\text { '... it breaks my heart to think anyone } \\
\text { could seriously be proposing to tear } \\
\text { down these iconic buildings... it would } \\
\text { rip the heart and soul out of the city. } \\
\text { This row should be listed, not } \\
\text { demolished.' (35) }\end{array}$ & $\begin{array}{l}\text { 'I cannot believe that a city like } \\
\text { Sheffield could consider demolishing } \\
\text { these pretty and interesting } \\
\text { buildings...It has character in a city } \\
\text { which lost so many old buildings in } \\
\text { WW2 and suffered the dead hand of } \\
60 \text { 's rebuild, much of which was often } \\
\text { inferior, uninteresting, ugly or has } \\
\text { already been demolished...these } \\
\text { buildings have intricate and beautiful } \\
\text { brick and plasterwork.' (38) }\end{array}$ & $\begin{array}{l}\text { 'The buildings under threat are unlisted } \\
\text { heritage assets and form part of the } \\
\text { setting of The Grade II listed } \\
\text { Wharncliffe Fireclay Works and } \\
\text { adjoining show room... The application } \\
\text { ignores heritage values and focusses on } \\
\text { the townscape value of the } \\
\text { buildings...For the above reasons, and in } \\
\text { the absence of clear and convincing } \\
\text { economic, environmental or social } \\
\text { benefits attached to this scheme, the } \\
\text { application should be rejected under } \\
\text { NPPF para I } 32 . \text { ' (54) }\end{array}$ \\
\hline $\begin{array}{c}\text { Unnecessary } \\
\text { Type of } \\
\text { Development }\end{array}$ & $\begin{array}{l}\text { 'I have lived in the Devonshire } \\
\text { Quarter for ten years and love the } \\
\text { vibrancy and diversity of the area. To } \\
\text { demolish these independent shops } \\
\text { and replace them with more } \\
\text { restaurants/bars/apartments would } \\
\text { ruin the character and the feeling of } \\
\text { the neighbourhood...'(I4) }\end{array}$ & $\begin{array}{l}\text { 'If there's no affordable and inspiring } \\
\text { buildings left for musicians, artists, } \\
\text { independent shops, and other creative } \\
\text { people in Sheffield because it has all } \\
\text { been replaced with soulless modern } \\
\text { boxes, what does the city have left to } \\
\text { offer anyone, other than its parks??' } \\
\text { (I2) }\end{array}$ & $\begin{array}{l}\text { 'We have enough cafés and } \\
\text { restaurants in the area. Please let us } \\
\text { keep one small pocket of character in } \\
\text { the city centre. It is already generic } \\
\text { enough as it is without taking shops } \\
\text { away from providers of unique, } \\
\text { inspiring and interesting goods' (36) }\end{array}$ & $\begin{array}{l}\text { 'First, there is a strong economic case } \\
\text { for keeping these unique buildings and } \\
\text { businesses... When the (Education } \\
\text { Institution) "markets" the city to } \\
\text { prospective students, these businesses - } \\
\text { and others like them - are an important } \\
\text { part of the city's identity. In contrast, } \\
\text { there is already an over-supply of } \\
\text { featureless apartments and dull chain } \\
\text { cafes.' (I04) }\end{array}$ \\
\hline $\begin{array}{c}\text { Character of } \\
\text { Devonshire } \\
\text { Quarter }\end{array}$ & $\begin{array}{c}\text { 'One of the more endearing qualities } \\
\text { of Devonshire Green is its almost } \\
\text { quirky mix of old and new., this is } \\
\text { what gives the area its quality and } \\
\text { attraction.' (8) }\end{array}$ & $\begin{array}{c}\text { '... you clearly do not realise or } \\
\text { appreciate what you have. devonshire } \\
\text { street is absolutely priceless, and one of } \\
\text { the reasons we are frequent visitors to } \\
\text { sheffield.' (48) }\end{array}$ & $\begin{array}{l}\text { 'Aesthetically the buildings have an } \\
\text { important role in framing the Green } \\
\text { at the centre and form part of the } \\
\text { eclectic character of the zone which } \\
\text { runs into Division Street and its } \\
\text { unique character. To lose this section } \\
\text { of the block may initiate the beginning }\end{array}$ & $\begin{array}{l}\text { 'Creative Sheffield's marketing headlines } \\
\text { for the city affirm the city's strong } \\
\text { identity based on "Authenticity and } \\
\text { Independence" - a sentiment most } \\
\text { Sheffielder's can be proud of...' (9) }\end{array}$ \\
\hline
\end{tabular}




\begin{tabular}{|c|c|c|c|c|}
\hline & & & $\begin{array}{c}\text { of a steady reduction of the areas } \\
\text { unique character.' (9) }\end{array}$ & \\
\hline $\begin{array}{l}\text { Perceptions } \\
\text { of New } \\
\text { Development } \\
\text { in Sheffield }\end{array}$ & $\begin{array}{l}\text { 'Other cities manage to integrate new } \\
\text { with old why do we seem to be } \\
\text { driven towards a blank canvas ? Surely } \\
\text { it is not beyond the designers / } \\
\text { developers capabilities to utilise the } \\
\text { existing buildings.' (8) }\end{array}$ & $\begin{array}{c}\text { 'Yet again a bit of Sheffield's beautiful } \\
\text { personality will die and be replaced } \\
\text { with corporate, dull businesses ... Leave } \\
\text { a little personality in our city. This is } \\
\text { not Leeds!' (39) }\end{array}$ & $\begin{array}{l}\text { 'Maybe some concrete cows on } \\
\text { Devonshire Green, then we would be } \\
\text { one step closer to being as soulless } \\
\text { and boring as Milton-Keynes.' (52) }\end{array}$ & $\begin{array}{c}\text { '...go against the need for sutainable } \\
\text { development rather than demolish and } \\
\text { new build.' }(5-2)\end{array}$ \\
\hline $\begin{array}{l}\text { Perceptions } \\
\text { of Sheffield } \\
\text { City Council }\end{array}$ & $\begin{array}{l}\text { 'This is the further selling out of local } \\
\text { communities in the pursuit of profit } \\
\text { for a small group of companies who } \\
\text { do not reinvest it in the local } \\
\text { area... The council should be ashamed } \\
\text { of itself for allowing further } \\
\text { gentrification of Sheffield under the } \\
\text { guise of buildings that need } \\
\text { demolishing.' (19) }\end{array}$ & $\begin{array}{l}\text { 'The Council yet again finishing off what } \\
\text { the Luftwaffe began. Appalling. } \\
\text { Appalling. Shame on you.' (82) }\end{array}$ & & \\
\hline
\end{tabular}

Table I: Examples of Public Comments Organised by Key Theme and Knowledge Type (Knowledge types adapted from Sandercock, 1998, Comments from Anonymous, 2014) 
This also demonstrates how comments ranged from the building specific scale, through to the local area and city scales, suggesting how the building and businesses are seen as serving publics that are defined up to the city scale and beyond. Similarly, a common perception was the tendency of new development proposals to be designed for (inter)national chain businesses. Other commenters linked their own experiences to those of future generations, invoking a duty of care towards them:

Wow, I've never seen so many people objecting to a planning application. Surely this shows the depth of feeling about why this building of special character should be preserved for future generations to enjoy.

I spent my formative years browsing and buying from Rare and Racy. I would sincerely like to see future generations do the same.

(Anonymous, 2014, emphasis added)

Both aspects can be linked back to the identification of the public as a matter of scale, respectively in terms of geography and time.

Echoing the spirit of communicative planning and Dewey's (1954) emphasis on self-organisation and, it is also notable how the use of an online system generated cross-references between comments:

Others have been more eloquent in their defence. I will just say, don't do it!

Whilst the objection written by (Organisation Name) is probably written in better planning Speak, but as a non-planner l'd like to add my comments too.

(Anonymous, 2014)

This does not overcome the self-selective nature of those commenting but does suggest further research is needed on such systems' potential to generate consensus. Moreover, later discussion of the Officer Report for the application explicitly illustrates the lack of influence of anything other than comments based on 'technical' knowledge.

\section{Lack of Space for Mutual Learning}

Despite the building's private ownership, the author experienced a common misconception amongst customers that SCC owned the building and were evicting the businesses involved to redevelop it. Within the comments, this is reflected in the framing of SCC as complicit in the demolition:

The area of Sheffield's city centre which you are planning to annihilate is the very thing which gives it it's charm and individuality... Destroy this and you destroy Sheffield. The only reason I go to town to shop is to visit the independent retailers in this section of town, kill this and you will finish off an already depressed center.

(Anonymous, 2014, emphasis added) 
The Council was incorrectly assumed to have the ability to dictate the form and nature of the redevelopment proposal. In reality, without exercising compulsory purchase powers, SCC's power was limited to making a decision on the submitted proposal, with some limited scope for negotiating changes. In turn, this highlights the lack of space in the process for mutual learning between the Council and wider public.

SCC's 'ownership', whether literal or metaphorical, is reflected in other comments, their inaccuracy making it difficult to account for them within the decision-making process:

If you can guarantee that the space will only be offered to a local business and non-chain establishment l'd be more inclined to go with such a proposal but we all know that this will not happen and you'll take cash from the highest bidder of whom only the likes of Weatherspoon's or other shite establishment will entertain.

...this is just another example of Sheffield City Council slowly eating away at the creative roots of Sheffield whether it be art, music or crafts.

SCC quite obviously have no real idea of what makes the city unique. Instead, they care about nothing more than profit from big business and homogenising the city to become another glossy, branded strip.

(Anonymous, 2014, emphasis added)

The comments illustrate frustration at the Council's apparently poor understanding of the significant emotional attachment associated with Devonshire Street, again illustrating the disconnect between widely held values and the more narrowly framed concerns of the regulatory system. However, this is also interpretable as frustration at a lack of ability to influence such decisions, leading to comments that directly criticise SCC's actions. These move from being agonistic, in the sense of putting forward group interests, to being antagonistic in the way that they make 'personal' attacks.

This prompts questions about what comments might have been made were they not based on misinformation and, consequently, whether better informed public commentary may have more clearly influenced the decision-outcome; not necessarily changing the material considerations but ensuring a more equitable approach to accounting for the interests of more-localised publics. There is no systematic mechanism for counteracting misinformation and facilitating mutual learning; consequently there is no opportunity for participants to modify their interests, maintaining an uneven power relationship that privileges those with technical knowledge of the regulatory system.

\section{The Protest, Petition, National Media and Famous Musicians}

Similar themes appear in statements from Labour Party and Green Party politicians, as representatives of localised publics; the former asserts that the 'city centre must offer something different to Meadowhall ${ }^{4}$ and independent shops are central to that' (Blomfield, 20I4), highlighting

\footnotetext{
${ }^{4}$ Meadowhall is a large shopping centre on the edge of Sheffield, part of the city's 1980s regeneration following industrial decline, but also considered to have undermined the city centre.
} 
heterogeneity's role in creating vibrant places. Hinting at the role of planning regulation, the latter notes:

The council has not updated the guidance for 10 years and has not adhered to what there is, so gradually the area... has succumbed to big chain coffee shops, restaurants and bars.

(Creasy, 20I5)

Both statements highlight the politicisation of the case, to an extent portraying these as matters of unbound choice, in comparison to the Council's lack of ownership and consequent lack of ability to regulate the proposal's form directly.

The proposal attracted national media attention, with articles in the Guardian newspaper highlighting the loss of independent businesses and heritage value (Waugh, 20I5; Collier, 20I4). Another article appeared in the New Musical Express (Renshaw, 20I4), a longstanding music magazine, focussed on the bookshop and clothing label and their links to Sheffield's creative history, following the intervention of well-known musicians; the 'Artic Monkeys' and 'Drenge'.

Similarly, a petition seeking to prevent the demolition highlights the 'creativity and independent entrepreneurial talent' (Butcher, 2014) associated with the bookshop and clothing label, but not the bed store. At time of writing the petition has attracted nearly 22,000 signatures.

On the day of the decision, a protest was held outside Sheffield Town Hall, attracting hundreds of people, and accompanied by several protestors making statements to the planning committee, objecting to the proposal.

Overall, these interventions highlight the question of balance when considering what is in the public interest; are they about protecting independent business as an intrinsically shared value? Or are they a narrower matter of direct interest, about the loss of particular businesses? Whilst the former is more abstract and does not prioritise any one business, the latter requires judgements about specific businesses.

Echoing the written comments, these interventions highlight the planning system's struggle to value knowledges that don't fit with its regulatory nature; the articles highlight an emotional attachment to the occupant businesses and the building's character, yet these are difficult to make 'objective' when weighed against measures of heritage value such as originality and integrity, and sustainability measures, such as walkable distance and housing provision. This links to professional judgement, and the need to move beyond analysing and comparing similar types of knowledge, to examining the consequences of synthesising multiple knowledges (Campbell, 20I2).

\section{Judicial Review as a Last Resort}

One group applied for the process to be judicially reviewed, to determine whether the Council had accounted for everything it should in reaching its decision. The application claimed that requirements to consider the proposal's impact on nearby listed buildings had not been fully met, slightly different to the public comments' focus on heritage loss (' $R$ (on the application of Nicholas Simon Roscoe Ltd) v. Sheffield City Council', 20I5a). However, the claim was rejected on the basis that the impact had been considered and judged unharmful (' $R$ (on the application of Nicholas Simon Roscoe Ltd) v. Sheffield City Council', 20I5b). 
In addition to highlighting more-localised publics' greater ability to participate, the judicial review application can be framed as a tactical, antagonistic manoeuvre; an indirect way of achieving the petitioner's aims, in light of a lack of third party right of appeal in English planning ${ }^{5}$. Conversely, this further highlights the power imbalance between those seeking to participate from outside, and those inside the system, explicitly involved in operating it (Forester, 1989).

\section{The Planning Decision}

As noted, legislation and policy can be framed as translating widely held values and interests into regulation, to address predictable aspects of the public interest on behalf of dispersed publics (Dewey, 1954). This use of regulation is efficient, allowing values to structure planning decisions without needing to be continually rationalised. Examining the final decision shows how this comes together with more-localised, specific, but more difficult to codify, interests, as expressed through participation.

It is widely documented that the English planning system is driven by an ambiguous yet powerful 'presumption in favour of sustainable development', promoting economic growth by assuming that proposals are acceptable unless proven otherwise. Overall, the National Planning Policy Framework (MHCLG, 2019) sets a clear narrative around the importance of economic growth. This can be framed similarly to housing shortage and urban sustainability in setting an abstract value that should guide planning decisions.

Also relevant is the Use Classes Order (UCO, HM, Government, 1987; 2020), which codifies limitless possible building uses into categories. Illustrating the efficiency of regulation, this arguably provides coherent terminology, facilitating shared understanding and giving the time-poor planner clear pointers for what impacts to consider. Reade (1987) describes this categorisation as a distinctive feature of the English system, but highlights its vagueness, 'since they relate to 'nominal' uses rather than socio-economic realities' (p.I2).

Applicants must describe their proposal using these categories, whilst municipalities can use them in policy to describe the local acceptability of different uses. The original proposal here is described as providing '393SQ M OF GROUNDFLOOR COMMERCIAL SPACE (A3)...' (Primesite Ltd., 20I4), translating to the provision of space to be used as a restaurant (HM Government, 1987). However, the UCO provides little scope for a decision-maker to consider whether the intended tenant is an (inter)national chain or an independent business:

...there is no protection in legislation for the individual occupants of buildings as the planning system relates to the development of the use of land and buildings, not to the user. For example, the planning system could do nothing to protect Rare and Racy should the landlord decide not to extend their lease and thereafter let the premises to a hairdresser or other AI retail premises.

(Hope, 20I5, p. I0)

\footnotetext{
${ }^{5}$ Although reconsidered by the Conservative-led Coalition government (DCLG, 2013), the English planning system does not include a right of appeal for parties who are not the applicant. For third parties this leaves judicial review of the decision-making process (not the decision itself) as the only route by which a decision can be reviewed.
} 
Taken from the Officer Report, the quote's tone implicitly acknowledges concern about this issue, but clearly identifies the difficulty of codifying the value associated with independent businesses, such that it was not given weight as a material consideration.

Similarly, in relation to the heritage value of the buildings, the Report argues that 'the weight that can be given to their conservation is considered to be limited' (Hope, 20I5, p.27-28); an implicit judgement that little or no weight should be attached to the vast majority of comments rationalised through the use of experiential or local knowledge, where there is no 'technical' knowledge being used to underpin this. Conversely, the Report explicitly upholds the values of compact urban form and housing need, addressing the interests of dispersed publics, but also values that have a long been identified as valid planning concerns and therefore translated into local policy (SCC, 2009).

Overall, the Report highlights a lack of grounds to refuse the proposal, reflecting the presumption in favour of sustainable development (MHCLG, 2019); the resulting recommendation to approve the proposal is arguably a sound conclusion within the perceived limits of policy and the regulatory system. However, the Report also holds clues as to how this conclusion might be synthesised with more-localised interests around maintaining independent businesses.

\section{Seeking Space to Manoeuvre within the System}

When applications for new development are submitted, there is some scope for changes to be negotiated with the applicant to make proposals more acceptable, prior to the final decision. In addition to aforementioned apartment mix changes, the Officer Report clarifies how the proposal was also modified to address public concerns about character and use, whilst emphasising the limits to this:

The proposals have therefore been amended to incorporate an AI retail unit... This arrangement... retains two thirds of the linear ground floor frontage of the block in shopping use and, on this basis, it is considered that the development could not resisted on the basis of proposal 7.2 of the Devonshire Quarter Action Plan.

(Hope, 20I5, p.12)

Reflecting this paper's core theme, it is the small retail unit's inclusion that illustrates how morelocalised values can fit into a planning system built around regulation, including how individual proposals fit within a context of cumulative change. The Devonshire Quarter Action Plan ${ }^{6}$ required that no more than a third of frontages in this part of the city should be non-retail in use (SCC, 2000). Building on the Action Plan, Sheffield's current planning framework envisions Devonshire Quarter as 'a thriving, distinctive and vibrant area with city living, niche shops, restaurants and bars and a variety of business uses...' (SCC, 2009, p.52), setting down in policy the contributions of independent businesses.

This requirement therefore highlights the possibility of translating the intrinsic value of independent business into a measurable policy criterion. Conversely, usage of the word 'resisted' suggests underlying frustration at the perceived limited scope for the officer to judge how the proposal would might best address the needs of independent business; a planner free to make an

\footnotetext{
${ }^{6}$ Afforded policy status by adoption as a Supplementary Planning Document. Following the UCO's consolidation in September 2020, which now places restaurants, retail and office uses in the same 'Class E' (HM Government, 2020), it may be more difficult to enforce this policy.
} 
independent professional judgement may have concluded that the retail unit should have been subdivided into multiple smaller units.

\section{I. Post Decision Politics}

After the Planning Committee's decision to approve the proposal, the subsequent statement released by one of the Council's Cabinet Members is interesting in several aspects:

We are in an extremely difficult situation that is frustrating for the Council, because although technically we make the decision on planning applications, our hands are tied by the stringent planning laws set out by the government. If we did not follow these laws we would be putting the Council under a big risk of being taken to an appeal by the developer, to be heard by the National Planning Inspectorate, which would mean that the Council would be overruled and the development go ahead, but with the Council facing huge legal bills. What we need to see is the Council being given the powers to make the decisions to shape the future of our high streets, so we can make the decisions locally, listening to the views of local people rather than having to follow arbitrary rules made up by bureaucrats in Whitehall.

(Bramall, 20I5)

This is interpretable as a reluctance to test the definition of material considerations, in light of the threat of the Council's conclusions being tested at appeal. However, it is ambiguous whether the suggestion of 'huge legal bills' refers to the Council having to defend the appeal, or the danger of having to pay the developer's costs should it lose. For this case, the Planning Inspectorate's (2020) guidance indicates that the significant public concern would increase the likelihood of adopting a formal inquiry procedure, with each party represented by a legally trained advocate, leading to significantly higher costs when compared with self-representation in an informal hearing. The guidelines clarify that costs may be awarded when one side has acted unreasonably; not about the professional judgement made, but whether the 'evidence' was accounted for appropriately in making that judgement.

As such, the characterisation of cost implications is not unfounded, and emphasises to the public a lack of control, though this is arguably over-emphasised. The emotive language positions the Committee as helpless, drawing attention to how municipal budget cuts may influence decisionmaking; would they have refused the proposal and risked an appeal if central government had not cut English local government funding 60\% since 2010 (LGA, 20I8)? Any answer would be speculative but this does illustrate how austerity and the presumption in favour of development interact to tilt the balance in favour of private proposals, by narrowing what can be confidently considered as 'valid' concerns when weighing up material considerations.

Overall the statement usefully encapsulates a theme that runs throughout the decision-making process. The language used arguably communicates an implicit desire to refuse the proposal, tacitly acknowledging public concern, but where the parameters for decision-making are perceived as narrowed by the need to follow policy, within the wider context of austerity.

\section{Conclusions}


Fundamental to this paper is how the English planning system embeds a distinctive relationship between professional judgement, discretion and regulation when making decisions about what is in the public interest. Underpinning this is the tendency of the current decision-making process to exacerbate an uneven power relationship between those inside the system and the wider public, by failing to provide those outside the system with the necessary basis for equitable participation.

The extent and variety of public participation clearly demonstrated the importance placed on independent business and heritage conservation by the local public, situated within concerns for how Devonshire Street, and Sheffield more widely, are experienced. Similarly, national media involvement indicates how these interests are linked to more widely held values. However, the written comments also demonstrate how this was not based on shared understanding of information. Whilst an agonistic process is arguably necessary to allow judgements to be made about the interests of those who cannot participate, a more dialogical process, facilitating mutual learning, shared understanding and the correction of misinformation, would allow participants to make more persuasive arguments.

Conversely, the case highlights the potential for localised interests and values to be accommodated within the more abstract but widely shared values associated with sustainability, highlighting the usefulness of scale as a way of identifying and synthesising the values and interests or more-abstract and more-localised publics; it is arguable that accommodating localised interests around heritage and independent business, as exemplified by the negotiated addition of the small retail unit, could have led to a more vibrant, locally specific interpretation of sustainability. However, the same detail exposes how a national focus on economic growth, and the mechanisms used to operationalise this, were perceived to limit the scope for more inclusive compromises.

In considering how this perceived lack of discretion was shaped, it is noteworthy that judgement and discretion are less likely to be scrutinised when they lead to a proposal's approval, with limited opportunities to review decisions for parties other than the applicant. Yet, the constraints of a central government mandated push for allowing development, taken with the potential financial consequences of losing a planning appeal in an era of austerity, were perceived as preventing the City Council from requiring the whole ground floor to be divided into small units. Furthermore, a more nuanced approach might have mandated maintaining at least parts of the existing building, in response to a clear emotional value associated with its age and character.

The language used by those inside the system suggests frustration at not being able to more comprehensively enrol these more-localised interests as material considerations. Consequently, the case suggests the need to allow planners and elected members more discretion when determining and assigning weight to material considerations when exercising their professional judgement, in addition to the imaginative use of policy and regulation. This includes an ability to place greater weight on non-technical knowledges such as emotional attachment, in order to address the disconnect between a system narrowly framed around valid, codified planning concerns and the wider, often less easily codified concerns of the public and how they experience places.

The consequent need is to revitalise a planning profession more confident in its normative purpose; to shape better places in the public interest, and consequently less reliant on the regulatory effect of policy and legislation. This is not to deny the important role of regulation in 
ensuring the public interest is accounted for but a definite move toward negotiation and situated judgement on Reade's (1987) spectrum.

At time of writing the buildings are empty of occupants, but no demolition has yet taken place. After the outpouring of emotional attachment, the objective logic of financial viability has not deemed it worth implementing the proposal, five years after its approval. Overall, the case highlights a need for regulation that moves from a narrow range of interests as they can be codified and accommodated whilst making financial profit, toward mandating the negotiation of compromise solutions that serve a wider range of public interests, as they are expressed through a wider range of knowledges, with more space to develop shared understandings. 


\section{Acknowledgements}

The author is very grateful to the guest editors for organising the initial 'Rethinking Regulation' symposium, and for their comprehensive and constructive comments on earlier drafts. In addition, the author thanks fellow symposium participants for their insightful notes and his husband for the initial idea and encouragement to write about the case.

\section{References}

ALEXANDER, E. (2002), 'The Public Interest in Planning: From Legitimation to Substantive Plan Evaluation', Planning Theory, I, 226-249.

ANONYMOUS (2014), Planning - Application Comments, https://planningapps.sheffield.gov.uk/onlineapplications/applicationDetails.do?activeTab=neighbourComments\&keyVal=NCIWIKNYFY000 (Accessed 15th November 2020).

BLOMFIELD, P. (20I4), My Concerns About the Devonshire St Demolition Plans, https://www.facebook.com/paulblomfieldmp/posts/like-lots-of-people-im-concerned-by-the-plansto-demolish-some-of-sheffields-mos/I015228090076I734/ (Accessed 17th March 2019).

BRAMALL, L. (20I5), Campaigners protest demolition of historic buildings on Sheffield's Devonshire Street, https://www.itv.com/news/calendar/2015-03-24/campaigners-protest-demolition-of-historicbuildings-on-sheffields-devonshire-street/ (Accessed 5th November 2020).

BUTCHER, J. (2014), Stop the demolition of Devonshire Street, Sheffield, https://you.38degrees.org.uk/petitions/stop-the-demolition-of-devonshire-street-sheffield-I (Accessed 17th March 2019).

CAMPBELL, H. (2006), 'Just Planning: The Art of Situated Ethical Judgement', Journal of Planning Education and Research, 26, 92-106.

CAMPBELL, H. (2012), 'Planning to Change the World: Between Knowledge and Action Lies Synthesis', Journal of Planning Education and Research, 32, I35-146.

CAMPBELL, H. and MARSHALL, R. (2000), 'Moral Obligations, Planning and the Public Interest: A Commentary on Current British Practice', Environment and Planning B. 27, 297-3 2.

CAMPBELL H. and MARSHALL R. (2002), 'Utilitarianism's Bad Breath? A Re-evaluation of the Public Interest Justification for Planning', Planning Theory, I, I63-I87.

CODA PLANNING (2014), Devonshire Street / Westhill Lane, Sheffield: Sustainability Statement, Sheffield, Coda Planning.

CODA PLANNING (2015), Devonshire Street Visuals, https://planningapps.sheffield.gov.uk/onlineapplications/files/B357D8F5BA20666 I I02339BEAAAD62F6/pdf/I4_03473_FUL-VISUALS87430I.pdf (Accessed 18th April 2019). 
COLLIER, H. (20I4), Sheffield residents fight plans to bulldoze independent shops,

https://www.theguardian.com/uk-news/the-northerner/20I4/oct/23/sheffield-devonshire-quarterpetition-development (Accessed 17th March 2019).

CREASY, J. (2015), Jillian Creasy on Devonshire Street demolitions, http://archive.sheffieldgreenparty.org.uk/20I5/03/24/jillian-creasy-on-devonshire-street-demolitions/ (Accessed 17th March 2019).

DAVIDOFF, P. (1965), 'Advocacy and Pluralism in Planning', Journal of the American Institute of Planners, 3 I, $33 \mid-338$.

DAVIES, R. (20I8), Network Rail sells railway arches to investors for $t I .5 \mathrm{bn}$, https://www.theguardian.com/business/20I8/sep/I0/network-rail-sells-railway-arches-real-estateinvestors-telereal-trillium-blackstone-property-partners (Accessed 17th March 2019).

DCLG (DEPARTMENT OF COMMUNITIES \& LOCAL GOVERNMENT) (2013), Technical Review of Planning Appeal Procedures: Consultation Summary of Responses, London, Department of Communities \& Local Government.

DDCMS (DEPARTMENT FOR DIGITAL, CULTURE, MEDIA \& SPORT) (2018), Principles of Selection for Listed Buildings, London, Department for Digital, Culture, Media \& Sport.

DEWEY, J. (1954), The Public and Its Problems, Athens, Ohio University Press.

EASTWOOD \& PARTNERS (2014), 162 - I 70 Devonshire Street, Sheffield Structural Condition Report, Sheffield, Eastwood \& Partners.

EDINA (202I), Digimap OS Roam, https://digimap.edina.ac.uk/roam/map/os (Accessed I8th February 202I) FLATHMAN, R. (1966), The Public Interest, New York, John Wiley \& Sons.

FORESTER, J. (1989), Planning in the Face of Power, Berkeley, University of California Press.

FRASER, N. (2008), Scales of Justice: Reimagining Political Space in a Globalizing World, Cambridge, Polity Press.

HEALEY, P. (2003), 'Collaborative planning in perspective', Planning Theory. 2, I0I-124.

HEALEY, P. (2006), Collaborative planning: shaping places in fragmented societies, Basingstoke, Palgrave Macmillan.

HILLIER, J. (2004), “Agon'izing Over Consensus: Why Habermasian Ideals cannot be 'Real", Planning Theory, 2, 37-59.

HCCPA (HOUSE OF COMMONS COMMITTEE OF PUBLIC ACCOUNTS) (2019), Network Rail's sale of railway arches: One Hundred and Thirteenth Report of Session 2017-19, London, House of Commons.

HM GOVERNMENT (1987), The Town and Country Planning (Use Classes) Order 1987, London, The Stationery Office.

HM GOVERNMENT (2004), Planning and Compulsory Purchase Act 2004, London, The Stationery Office. 
HM GOVERNMENT (20I5), Town and Country Planning (Development Management Procedure) (England) Order 2015, London, The Stationery Office.

HM GOVERNMENT (2020), The Town and Country Planning (Use Classes) (Amendment) (England) Regulations 2020, London, The Stationery Office.

HOPE, D. (2015), Committee Officer Report, https://planningapps.sheffield.gov.uk/onlineapplications/files/79IA5B33F3D28A46FA0EFF99C24B0AD4/I4_03473_FULCOMMITTEE_OFFICER_REPORT-876670.rtf (Accessed I7th March 2019).

LGA (LOCAL GOVERNMENT ASSOCIATION) (20I8), Local services face further $€ l .3$ billion government funding cut in 2019/20, https://www.local.gov.uk/about/news/local-services-face-further-ps /3-billiongovernment-funding-cut-201920 (Accessed 17th March 2019).

LOCALITY (2017), Powerful Communities, Strong Economies: The final report of the Keep it Local for Economic Resilience Action Research Project, London, Locality.

MAIDMENT, C. (2016), 'In the Public Interest? Planning in the Peak District National Park', Planning Theory, I5, 366-385.

MAKOFF, R. \& READ, R. (2018), 'Beyond Just Justice - Creating Space for a Future-Care Ethic', Philosophical Investigations 40, 223-256.

MCCLYMONT, K. (20I I), 'Revitalising the Political: Development Control and Agonism in Planning Practice', Planning Theory, 10, 239-256.

MHCLG (MINISTRY OF HOUSING, COMMUNITIES AND LOCAL GOVERNMENT) (2020), Determining a planning application, https://www.gov.uk/guidance/determining-a-planning-application (Accessed 26th July 2020).

MHCLG (MINISTRY OF HOUSING, COMMUNITIES AND LOCAL GOVERNMENT) (2019), National Planning Policy Framework, London, Ministry of Housing, Communities and Local Government.

MOUFFE, C. (2005), On the Political, Abingdon, Routledge.

NATIONAL ASSEMBLY FOR WALES (2015), Well-being of Future Generations (Wales) Act 20I5, London, The Stationery Office.

NUSSBAUM, M. (2008), Martha Nussbaum - Part I - The Social Contract, https://www.abc.net.au/radionational/programs/philosopherszone/martha-nussbaum---part-1--the-social-contract/3174420 (Accessed I8th February 202I)

O’NEILL, O. (2000), Bounds of Justice, Cambridge, Cambridge University Press.

PRIMESITE LTD. (20I4), Application for Planning Permission. Town and Country Planning Act 1990, https://planningapps.sheffield.gov.uk/onlineapplications/files/EE I I 2AEEF69 | 7963F90CE4A583C0FEFD/pdf/ I4_03473_FUL--819706.pdf (Accessed 17th March 2019). 
'R (ON THE APPLICATION OF NICOLAS SIMON ROSCOE LTD) V. SHEFFIELD CITY COUNCIL' (2015a), High Court of Justice, Administrative Court, CO/215//20I5, https://planningapps.sheffield.gov.uk/onlineapplications/files/C21236454 ICA5268 IBB8862C10C76CDD/pdf/I4_03473_FULJUDICIAL_REVIEW_PAPERS_FROM_CLAIMANT-892604.pdf (Accessed 17th March 2019).

'R (ON THE APPLICATION OF NICOLAS SIMON ROSCOE LTD) V. SHEFFIELD CITY COUNCIL' (2015b), High Court of Justice, Administrative Court, CO/215//2015, https://planningapps.sheffield.gov.uk/onlineapplications/files/6AC848CICA8368C8C938BD442064E66B/pdf/I4_03473_FULJUDICIAL_REVIEW_-_JDGE_S_DECISION-910284.pdf (Accessed I7th March 2019).

READE, E. (1987), British Town and Country Planning, Milton Keynes, Open University Press.

RENSHAW, D. (2014), Arctic Monkeys and Drenge urge Sheffield council to save city's independent businesses, https://www.nme.com/news/music/arctic-monkeys-33-I24I35 I\#RFOffPBJ0xIVXk7G.99 (Accessed 17th March 2019).

ROYAL TOWN PLANNING INSTITUTE (2016), Code of Professional Conduct: As last amended by the Board of Trustee: Effective from 10 February 2016, London, Royal Town Planning Institute.

SANDERCOCK, L. (1998), Towards Cosmopolis, Chichester, John Wiley and Sons.

SCC (SHEFFIELD CITY COUNCIL) (2000), Devonshire Quarter Action Plan, Sheffield, Sheffield City Council.

SCC (SHEFFIELD CITY COUNCIL) (2009), Sheffield Development Framework Core Strategy: Adopted March 2009, Sheffield, Sheffield City Council.

SCR (SHEFFIELD CITY REGION) (2015), Strategic Economic Plan: A focused 10 Year Plan for Private Sector Growth 2015 - 2025, Sheffield, Sheffield City Region.

THE PLANNING INSPECTORATE, (2020), Procedural Guide: Planning appeals - England, Bristol, The Planning Inspectorate.

WAUGH, R. (20I5), Sheffield's Rare \& Racy: the independent music store Jarvis Cocker says it would be 'a crime to destroy', www.theguardian.com/cities/the-northerner/2015/mar/31/rare-and-racys-closure-jarviscocker (Accessed 17th March 2019).

WESSEX ARCHAEOLOGY, (2015), I62-I 70 Devonshire Street Sheffield, South Yorkshire: Archaeological Assessment and Building Appraisal, Sheffield, Wessex Archaeology.

YOUNG, I.M. (2000), Inclusion and Democracy, Oxford, Oxford University Press. 